\title{
Environment and Public Health in a Time of Plague
}

\author{
Victoria Sutton ${ }^{\dagger}$
}

\section{INTRODUCTION}

The environment and public health goals hold a common value of healthy populations. The threat of bioterrorism requires a partnership of both, building upon the long history of the link between public health and the environment. This existing relationship is key to an effective system of biodefense for the nation, because the use of biological weapons through every environmental pathway poses a potential threat. Contaminations of water, growing crops, grazing cattle, air through inhalation, dermal absorption, or consumption of food or water in the human environment are potential delivery methods. For these risks of bioterrorism in the environment, there is an existing federal regulatory and statutory framework upon which the relationship between the environment and public health can be strengthened and shaped. We took a narrower approach to public health priorities in the environment in 1962 with the publication of Silent Spring, ${ }^{1}$ which shifted the direct public health effects regulation to a broader environmental protection policy, which took a more comprehensive, holistic approach to human health.

This Article examines two important features of change in the post-9-11 relationship between public health, public health law, and environmental law. The first is an immediate change in the expansion of environmental laws to address biodefense activities of surveillance and response through either executive action or congressional amendment. ${ }^{2}$ The second and most pervasive change is the indication of a shift in federalism in public health law, in a way analogous to the development of federal environmental law in the last half of the twentieth century. This Article begins with an examination of the indications of a shift in federalism in public health, and then turns to the changing role of the U.S. Environmental Protection Agency ("EPA") and the application of existing environmental laws to new problems and controversies in bioterrorism.

$\dagger \quad$ Ph.D., Environmental Sciences, University of Texas at Dallas; J.D., American University; Professor of Law and Director of the Center for Biodefense, Law and Public Policy, Texas Tech University; Visiting Lecturer, Yale University (Fall 2004). She is the author of LAW AND SCIENCE: CASES AND MATERIALS (2001), LAW AND BIOTERRORISM (2003), and numerous articles. She is the former Assistant Director of the White House Office of Science and Technology Policy and White House EPA Liaison (1990-1993, during the George H.W. Bush Administration).

1 RACHEL CARSON, SILENT SPRING (1962).

2 See Victoria Sutton, Bioterrorism Preparation and Response Legislation-The Struggle to Protect States' Sovereignty While Preserving National Security, 6 GEO. PUB. POL'Y REV. 93 (2001). 


\section{THE SHIFT IN FEDERALISM AS A COURSE TOWARD AN EFFECTIVE BIODEFENSE}

Because modern federal environmental law has a well-established existing regulatory structure, shaped by more than three decades of experience, this framework can present major contributions to a national homeland defense built around federal environmental law expanding on the original effort to protect public health.

\section{A. SHifTING FEDERALISM AND ENVIRONMENTAL LAW}

The role today of the federal government in environmental protection is the product of the shift from state power over property law and water law, ${ }^{3}$ to federal power because of the substantial effect on interstate commerce from environmental pollution control and remediation, which has preempted these areas for state control. An example of this shift in federalism can be observed in the area of regulation of water pollution.

The first action by Congress involving the effects of dumping trash and materials into rivers was through the regulation of "navigable waters" in the U.S. Rivers and Harbors Act of $1899^{4}$ and the Refuse Act of $1899 .^{5}$ The primary purpose was to protect the rivers for navigation and to avoid impeding navigation traffic with trash or lumber and wood floating in the rivers obstructing shipping. ${ }^{6}$ The Water Pollution Control Act of $1948^{7}$ was the first comprehensive act to address the growing concern for water pollution but did little more than underscore states' responsibilities for water. This Act was replaced by the Water Pollution Control Act Amendments of $1956^{\circ}$ which were intended to "extend and strengthen" the 1948 Act, and emphasized the continuing responsibilities of the state in controlling water pollution. ${ }^{9}$ The House Report from the Committee on Public Works stated that:

The bill as reported reemphasizes the policy of the Congress to recognize, preserve, and protect the primary rights and responsibilities of the States in controlling water pollution .... Regulatory authority at the Federal level should be limited to interstate pollution problems and used on a standby basis only for serious situations and which are not resolved through State and interstate collaboration. ${ }^{10}$

The Act specified that "nothing in this act shall be construed as impairing or affecting any right or jurisdiction of the States with respect to their waters."11 The Public Health Service was designated as the lead agency with the goal of

3 See Richard L. Revesz, Federalism and Environmental Regulation: A Public Choice Analysis, 115 HARV. L. REV. 553, 578-83 (2001); Sutton, supra note 2, at 95.

$4 \quad 33$ U.S.C. $\S \S 401-67(2000)$.

533 U.S.C. $\$ 407(2000)$.

6 Paul Boudreaux, Federalism and the Contrivances of Public Law, 77 ST. JOHN'S L. REV. $523,552-53$ (2003).

7 Water Pollution Control Act of 1948, Pub. L. No. 80-845, 62 Stat. 1155 (1948) (codified as amended at 33 U.S.C. $\S \S 1251-1376$ ).

8 Water Pollution Control Act Amendments of 1956, Pub. L. No. 84-660, 70 Stat. 498 (1956) (codified as amended at 33 U.S.C. $\S \S 1251-1376$ ).

9 Water Pollution Control Act Amendments of 1956, H.R. REP. No. 1446, at 2 (1956), reprinted in 1956 U.S.C.A.A.N. (70 Stat. 498) 3023, 3023-24.

$10 \quad$ Id. at 3024.

11 Id. at 3026 . 
determining the "impact of new pollutants on public health and other vital water uses, and to find more practical and economically feasible abatement measures."12 The Surgeon General was given authority to develop comprehensive programs to implement and enforce this Act, but was at the same time prevented from issuing any regulations without the prior agreement of the states. ${ }^{13}$ The states were given grants to implement programs developed by the Surgeon General. ${ }^{14}$

In that same year, 1956, President Eisenhower vetoed the Rivers and Harbors Act of $1956^{15}$ because, among other reasons, it lacked the provision of state participation in the bill. ${ }^{16}$ In his veto message he stated that "vital water resources can best be conserved and utilized in the public interest if the Federal Government cooperates with State and local governments." 17

The inability to control water pollution by the federal government, because of the policy of leaving regulation to the states, was exacerbated by the reorganization of the federal oversight mechanism. Although the 1956 Act designated the Public Health Service as the agency charged with implementation, the Refuse Act of $1965^{18}$ changed the control to one of joint authority by the Public Health Service and the Commission appointed under the Federal Water Pollution Control Administration. ${ }^{19}$ The states were given the charge to develop standards for water quality within their jurisdictions. $^{20}$ In 1966, the Federal Water Pollution Control Commission was moved to the Department of Interior, ${ }^{21}$ keeping administration of the program in a state of instability.

The public pressure to address the growing problem of environmental pollution, which was not improving under states' control, culminated in the first Earth Day in 1970 with the signing of the National Environmental Policy Act, ${ }^{22}$ the first major federal environmental statute, and the creation of the U.S. Environmental Protection Agency. ${ }^{23}$ A growing environmental movement exploded in 1970 with this first Earth Day, marked by marches, celebrations, and a nationwide wave of determination to reverse the trend of polluting the environment and return the nation to its previous condition. ${ }^{24}$ Although prior to 1970 , Congress had passed statutes which directed states to give attention to limiting the pollution in their water and air, such rules could be avoided by the polluting industries by leaving any state with the tough regulations and seeking a more hospitable - and profitable-state. ${ }^{25}$ This

\footnotetext{
$12 \quad$ Id. at 3025.

13 Id.

$14 \quad$ Id.

15 H.R. 12080, 84th Cong. (1956).

16 President's Memorandum of Disapproval of Rivers and Harbors Act for 1956 (Aug. 10, 1956), reprinted in 1956 U.S.C.C.A.N. 4828.

17 Id.

1833 U.S.C. $\$ 1361$ (1965).

19 Water Pollution Control Act Amendments of 1956, Pub. L. No. 84-660, $\S 10,12,70$ Stat. 498 (1956), reprinted in 1956 U.S.C.C.A.N. 560, 570-71.

20 Id.

21 Federal Water Pollution Control Act Amendments of 1972, S. REP. NO. 92-414 (1972), reprinted in 1972 U.S.C.C.A.N. 3668, 3669-70.

2242 U.S.C. $\S \S 4321-4370$ a (2000) (signed into law by President Nixon on Jan. 1, 1970).

23 Exec. Order No. 11,548, 35 Fed. Reg. 11,677 (July 20, 1970).

24 See John N. Hanson, The Impact of the United States' Environmental Regulations on Innovation, 21 CAN.-U.S. L.J. 229, 229 (1995); Robert V. Percival, Separation of Powers, the Presidency, and the Environment, 21 J. LAND RESOURCES \& ENVTL. L. 25, 34 (2001).

25 A circuit court described this phenomenon as the "Tragedy of the Commons" which "might result if jurisdictions can compete for industry and development by providing more liberal limitations
} 
phenomenon became known as the "race to the bottom" with each state hoping to be the most attractive to businesses and factories which would bring employment and tax revenues to the state, and the way to attract them was to compete with other states, promulgating the least onerous regulations. ${ }^{26}$

Water quality standards were to be promulgated by the states, as required under the 1965 legislation, and the Committee Report described the process for that development: "[ $t]$ he States have first responsibility for enforcement of their standards. When approved by the Environmental Protection Agency, however, the standards for interstate navigable waters become Federal-State standards."27

A long history of litigation between states for polluting waterways ${ }^{28}$ and air $^{29}$ further gave rise to the interstate commerce clause basis for federal environmental regulation. ${ }^{30}$ Property law and water law, within the sovereign power of states, were areas among the "mass of legislation"31 which has never been surrendered by the states. However, the federalism relationship between the states and the national government was not intended to be unchanging, but rather flexible enough to accommodate the interests of the people. James Madison wrote in The Federalist Papers No. 46: "If, therefore . . the people should in future become more partial to the federal than to the State government, the people ought not to be precluded from giving most of their confidence where they may discover it to be most due . . . "32 The great pressure from the public with the groundswell of concern for the environment shifted the task to the federal government to overcome the interstate problems of air and water pollution as well as hazardous waste. ${ }^{33}$ The model has been identified as one of cooperative federalism.

In 1972, Congress enacted the Federal Water Pollution Control $\mathrm{Act}^{34}$ which established a national permit system to control all discharges of pollutants into surface waters to be implemented by the new federal agency, EPA. ${ }^{35}$

\section{B. Shift in Federalism in Public Health Law}

Bioterrorism and emerging infectious diseases threaten the public health in a way we have not seen in almost a century. ${ }^{36}$ States have had sovereignty in the area

than their neighboring states." National Resources Defense Council, Inc. v. Costle, 568 F.2d 1369, 1378 (C.A.D.C. 1975).

26 See Kirsten H. Engel, State Environmental Standard Setting: Is There a "Race" and Is It "to the Bottom"?, 48 HASTINGS L.J. 271, 274-76 (1997); Franz Xaver Perrez, The Efficiency of Cooperation: A Functional Analysis of Sovereignty, 15 ARIZ. J. INT'L \& COMP. L. 515, 538-42 (1998)

27 S. REP. NO. 92-414, at 4-5 (1971), reprinted in 1972 U.S.C.C.A.N. 3668, 3671-72.

28 See, e.g., Illinois v. City of Milwaukee, 406 U.S. 91 (1972); New York v. New Jersey, 256 U.S. 296 (1921); Missouri v. Illinois, 200 U.S. 496 (1906).

29 See, e.g., Pennsylvania v. West Virginia, 262 U.S. 553 (1923); Connecticut v. Long Island Lighting Co., 535 F. Supp. 546 (E.D.N.Y. 1982).

30 Hodel v. Virginia Surface Mining \& Reclamation Ass'n, 452 U.S. 264, 282 (1981).

31 Gibbons v. Ogden, 22 U.S. 1, 203 (1824).

32 James Madison, No. 46: Relative Strength of the Federal and State Governments, in THE ENDURING FEDERALIST 203, 204 (Charles A. Beard ed., 1948).

33 See Resource Conservation and Recovery Act of 1976 ("RCRA"), 42 US.C. $\S \S 6901-6991 \mathrm{i}$ (2000) (providing a federal statutory scheme for regulating hazardous waste); Comprehensive Environmental Response Compensation and Liability Act of 1980 ("CERCLA"), 42 U.S.C. $§ \S 9601$ 9675 (2000) (providing a federal statutory scheme for cleaning up pollution cites).

34 The Federal Water Pollution Control Act of 1972 ("FWOPCA" or "CWA"), 33 USC $\S$ $1251-1376(2000)$

35 ld. 
of public health since colonial existence, and preemption exists where food and drugs enter interstate commerce. ${ }^{37}$ Federal regulation of food and drugs began with the turn of the twentieth century and was intended to regulate risks to the public health. ${ }^{38}$ However, new threats of bioterrorism and emerging infectious diseases are regulated through the sovereign powers of states, not federal powers. ${ }^{39}$ But after the anthrax attacks in the Fall of 2001, the public expected the federal government to provide a defense against bioterrorism as a matter of national security. ${ }^{40}$ Consistent with the shifting federalism concept of the U.S. Constitution, interpreted through The Federalist's principle that "If . . . the people should in future become more partial to the federal than to the State government, the people ought not to be precluded from giving most of their confidence where they may discover it to be most due," in much the same manner as federal environmental law. ${ }^{42}$ The following developments in the area of biodefense and public health law are illustrative of the shift in federalism analogous to that of federal environmental law.

As outlined above, in 1956 states were given grants to begin to develop standards for water quality on a state-by-state basis. The failure of the states to use grants for consistent regulation from state to state, which would have ensured a uniform approach to environmental regulation, gave rise to state-shopping by polluting industries to find the state with the least regulation. ${ }^{43}$ Each state developed their own standards, leading to as many standards as there were states.

Just as grants to states to develop environmental water quality standards resulted in further creating a disjointed and uncoordinated state-by-state approach, the same approach has begun in preparation for bioterrorism. The Public Health Security and Bioterrorism Preparedness and Response Act of $2002^{44}$ provides for grants to states to develop plans for biodefense dispersed through the Centers for Disease Control and Prevention ("CDC") to the state departments of public health. ${ }^{45}$ A state-by-state approach to biodefense fails to encompass the overarching priority of national coordination in the event of an attack or the spread of an emerging infectious disease, which could spread much like the interstate nature of water and air pollution. Grants were also provided as a means to prepare for a bioterrorism attack

36 A smallpox epidemic in 1900 in Massachusetts, a plague epidemic in San Francisco in 1900 , the influenza pandemic of 1918, and the polio epidemic of the 1940s mark some of the most devastating diseases in the past century.

37 See James G. Hodge, Jr., The Role of New Federalism and Public Health Law, 12 J.L. \& HEALTH 309 (1998).

$38 \quad I d$. at 332.

39 See Wendy E. Parmet, After September 11: Rethinking Public Health Federalism, 30 J.L. MED. \& ETHICS 201, 202-03 (2002); Victoria Sutton, Bioterrorism Preparation and Response Legislation-The Struggle to Protect States' Sovereignty While Preserving National Security Federalism, 6 GEO. PUB. POL'Y REV. 2 (2001).

40 See Richard L. Berke \& Janet Elder, Survey Shows Doubts Stirring on Terror War, N.Y. TiMES, Oct. 30, 2001, at Al, B6.

41 Madison, supra note 32, at 204.

42 See Adam Babich, Our Federalism, Our Hazardous Waste, and Our Good Fortune, 54 MD. L. REV. 1516, 1532 (1995); Victoria Sutton, Biodefense-Who 's in Charge?, 13 HEALTH MATRIX 117 (2003).

43 William L. Andreen, The Evolution of Water Pollution Control in the United States-State, Local, and Federal Efforts, 1789-1972: Part II, 22 STAN. ENVTL. L.J. 215, 229-30 (2003).

44 Public Health Security and Bioterrorism Preparedness and Response Act of 2002, Pub. L. No. 107-188, 116 Stat. 694 (2002) (codified in scattered sections of 42 U.S.C.).

45 Id. 
through the Nunn-Lugar-Domenici Act, ${ }^{46}$ to provide funding to purchase new equipment and to attend training in biodefense, beginning well before 9-11 in the mid-1990s. ${ }^{47}$ The General Accounting Office ("GAO") cautioned against simply providing grants to the states for training and equipment, warning that "federal officials should be alert to the potential for these governments to use grants to substitute for their own resources in these programs, essentially converting a targeted federal grant into a general revenue sharing initiative." 48 Indeed, state and local governments, long neglected budget priorities, needed funding to obtain basics such as fax machines. Urging that national preparedness must hinge on the federal government's ability to form effective partnerships with nonfederal entities, the GAO argued that "federal initiatives should be conceived as national, not federal in nature," engaging not only local and state governments in partnerships, but also private partners. ${ }^{49}$

The triggering event for a movement in federalism occurred for federal environmental law in 1970 with the culmination of public demand for the federal government to address the growing problem of environmental pollution. The triggering event for a shift in federalism in public health law occurred with the anthrax attacks of the Fall of 2001, when the public demanded that the federal government provide the needed defense and response to the attacks. ${ }^{50}$ The role of $\mathrm{CDC}$, however, as stated in its mission, is merely to respond to the needs and requests of states for support and advice in public health matters. ${ }^{51}$ The public demanded more, and the Public Health Security and Bioterrorism Preparedness and Response Act of $2002^{52}$ provided a token expansion of CDC authority finding that "the Centers for Disease Control and Prevention has an essential role in defending against and combating public health threats and requires secure and modern facilities, and expanded and improved capabilities related to bioterrorism and other public health emergencies, sufficient to enable such Centers to conduct this important mission." 33 A closer examination of the section reveals only that an increase in facilities and training is mandated, ${ }^{54}$ rather than an expansion of their mission to fulfill this role of biodefense. However, the provision for the establishment of a system of public health alert communications and surveillance networks between federal, state, and local public health officials through the use of grants and cooperative agreements is a move away from exclusive state power and control to a more cooperative federalism. The use of surveillance of public health has always been a power of the states, and states are not, therefore, compelled to

46 Pub. L. No. 104-201, 110 Stat. 2718 (1996) (codified as amended at 50 U.S.C. $\S 2312$ $(2000))$

47 Id.

48 U.S. General accounting OfFice, Pub. No. GAO-02-886T, Homeland SEcurity: Proposal for Cabinet agency Has Merit, But Implementation Will Be Pivotal to Success 28 (2002).

49 Id. at 27.

50 GaO, Pub. No. GaO-04-152, Bioterrorism: Public Health Response to anthrax INCIDENTS OF 2001 4-5 (2003).

51 CENTERs FOR Disease CONTROL AND PREVEnTION, MANAGEMENT ANALysis AND Services OfFice, Centers for Disease CONTROL AND Prevention Mission, at http:// www.cdc.gov/maso/agency.htm (last reviewed Aug. 27, 2003).

52 Pub. L. No. 107-188, 116 Stat. 594 (2002) (codified in scattered sections of 42 U.S.C.).

53 Id.

54 Id. 
report any symptoms or diseases other than those reportable communicable diseases required by federal law. ${ }^{55}$

Just as the precipitating event of Earth Day began the shift in federalism in pollution control in environmental law, the precipitating event of the anthrax attacks of the Fall of 2001 has begun a shift in federalism in public health law. The federal government first identified the Public Health Service as the lead agency, followed by the creation of a Federal Water Pollution Control Commission to join with the Public Health Service in administration of water quality. ${ }^{56}$ Pollution control responsibilities were located first in the Public Health Service, then the Commission was made a part of the Department of Health, Education, and Welfare. ${ }^{57}$ Finally, the water pollution control authority was transferred to Department of Interior ${ }^{58}$ and then to the U.S. Environmental Protection Agency with its formation by Executive Order in 1970 by President Nixon. ${ }^{59}$ President Nixon created a new agency with a mission to implement federal environmental law, rather than to risk a "business-as-usual" response by the Department of Interior to the new duties of federal environmental law. ${ }^{60}$

The same reorganization strategy to combine effective federal offices within the Department of Homeland Security parallels the development of federal environmental law, in the shifting federalism responsibilities. President George W. Bush signaled three shifts in federalism in his proposal for the formation of the Department of Homeland Security. First, "the Department would set national policy and establish guidelines for state and local governments;" 61 second, the proposal makes the Department of Homeland Security "the lead agency preparing for and responding to . . . biological . . . terrorism," which takes part of the states' public health agencies' responsibility as described in the CDC biodefense plan; ${ }^{62}$ and third, the proposal directs that "The new Department would ensure that local law enforcement entities-and the public-receive clear and concise information from their national government," ${ }^{33}$ which again, takes part of the states' public health agencies' responsibility in originating their own public health information.

Figure 1 notes significant events in the evolution of federal environmental law, and the parallel with public health law.

55 See Exec. Order No. 13,295, 68 Fed. Reg. 17,255 (Apr. 4, 2003); 42 U.S.C. $\S 264$ (2000).

56 Andreen, supra note 43, at 222-42. .

57 See id. at 242-43; Robert F. Blomquist, Senator Edmund S. Muskie and the Dawn of Modern American Environmental Law: First Term, 1959-1964, 26 WM. \& MARY ENVTL. L. \& POL'Y REV. 509, 546 (2002).

58 Reorg. Plan No. 2 of 1966, 80 Stat. 1608 (1966).

59 Reorg. Plan No. 3 of 1970, 84 Stat. 2086, 2087, 2089 (1970).

60 John C. Whitaker, Earth Day Recollections: What It Was Like When the Movement Took Off, EPA J. (July/Aug. 1988), at http://www.epa.gov/history/topics/earthday/10.htm.

61 OfFICE OF HOMELAND SECURITY, NATIONAL STRATEGY FOR HOMEland SECURITY 2 (2002), available at http://www.whitehouse.gov/homeland/book/index.html.

62 Id.

63 Id. at 5. 
Figure 1: Timeline of the Development of Federal Environment Law with Recent Developments in Public Health Law

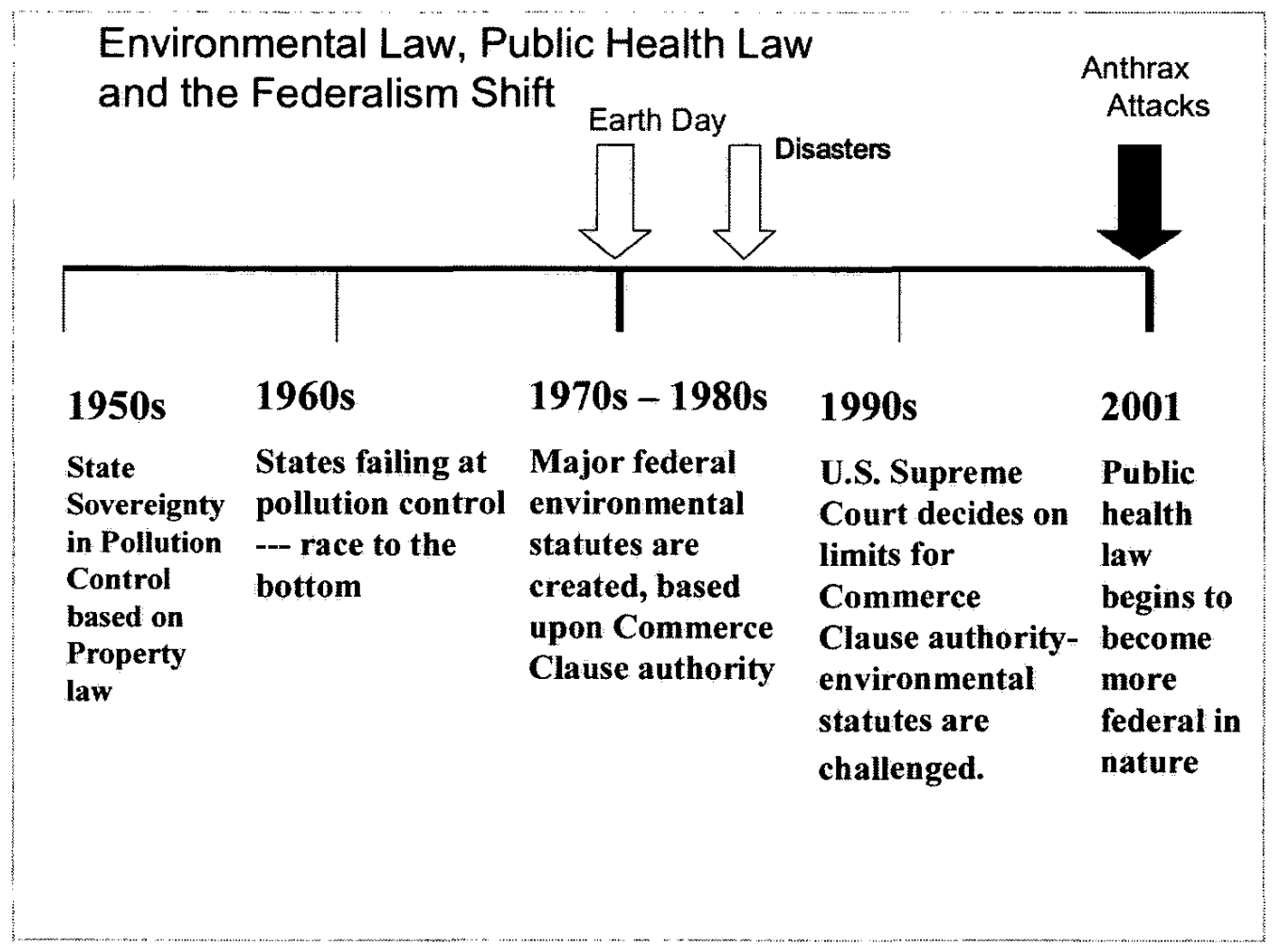

\section{ENVIRONMENTAL LAW AND HOMELAND DEFENSE}

\section{A. The Changing Role of EPA}

After the anthrax attacks of 2001, EPA Administrator Christine Todd Whitman announced that the agency would seek more authority to protect water supplies and to manage contaminated sites, saying, "[I]t's not about turf . . . [I]t's about the best way to respond and use all the resources we have available to us to meet our responsibilities in responding to biological attacks." $" 64$

The role of the Environmental Protection Agency has been interpreted within its stated mission in 1997 "to protect human health and to safeguard the natural environment - air, water, and land-upon which life depends." ${ }^{65}$ The mission was simplified in EPA's 2003 Strategic Plan: "Our mission statement is clear: to protect human health and the environment." ${ }^{.66}$ In February 1998, the EPA issued a Fact

64 Whitman Says EPA May Seek More Control Over Water Security, Bioterrorism Response, 32 BNA ENV'T REP. 2405 (Dec. 14, 2001).

65 OfFice of the Chief Financial Officer, EPA, Pub. No. EPA/190-R-97-002, EPA STRATEGIC PLAN 7 (1997), available at http://www.epa.gov/ocfo/plan/plan.htm.

66 EPA, 2003-2008 EPA STRATEGIC PLAN: DIRECTION FOR THE FUTURE 1 (2003), available at http://www.epa.gov/ocfo/plan/plan.htm [hereinafter 2003-2008 EPA STRATEGIC PLAN]. 
Sheet ${ }^{67}$ outlining their responsibilities for responses to terrorism, followed by a further directive in July 1998 which described the role in the Presidential Decision Directives 39,62 , and $63 .^{68}$ These stipulated that the EPA was to be a supporting agency by: (1) helping state and local responders plan; (2) coordinating with key federal partners; (3) training first responders; and (4) providing resources in the event of a terrorist incident. ${ }^{69}$ It further stipulated that "[b]ecause of [EPA's] inherent role in protecting human health and the environment from possible harmful effects of certain chemical, biological, and nuclear materials, EPA is actively involved in counter-terrorism planning and response efforts. $" 70$

The Nunn-Lugar-Domenici Act, which was among the first to address terrorism through providing grants for training for first responders at the local level, included EPA as a participant in this Domestic Preparedness Program. ${ }^{71}$

The President can provide direction of the operations of the Executive Branch through directives, which may be classified. In Presidential Decision Directives ("PDD") 39, 62, and 63 the responsibilities of each federal agency for terrorism events is outlined. $^{72}$ In these directives which have been redacted and declassified, the responsibilities of the U.S. Environmental Protection Agency include: "Assisting the FBI in determining what sort of hazardous substance may be, or has been, released in a terrorist incident; and following an incident, assisting with environmental monitoring, decontamination efforts and long-term site cleanup operations." ${ }^{73}$ The EPA has served as the lead federal agency for decontamination in responding to the 2001 anthrax attacks and their largest new budget increases for FY 2003 were in the area of decontamination research and development at $\$ 75$ million, which comprised more than half of the EPA budget for homeland security. ${ }^{74}$ The offices within EPA who are assigned counter-terrorism roles are: the Chemical Emergency Preparedness and Prevention Office; the Office of Emergency and Remedial Response; and the Office of Air and Radiation. ${ }^{75}$

The 2004 Strategic Plan describes an expanding commitment to decontamination activities in response to terrorism including bioterrorism, planning for a budget to address five such incidents. ${ }^{76}$ The Strategic Plan describes the movement toward more preparation for decontamination responsibilities because of expectations of EPA from the nation: "The Agency's crucial role in responding to the World Trade Center and Pentagon attacks, and the decontamination of anthrax at

67 Office of Solid Waste and Emergency Response, EPA, Pub. No. EPA 550-F-98-014, EPA'S ROLE IN COUNTER-TERRORISM ACTIVITIES: FACTSHEET (1998), available at http:// yosemite.epa.gov/oswer/ceppoweb.nsf/content/ct-publ.htm [hereinafter EPA FACTSHEET].

68 Presidential Decision Directive No. 39 (June 21, 1995), available at http://www.fas.org/irp/ offdocs/pdd39.htm [hereinafter PDD No. 39]; Presidential Decision Directive No. 62 (May 22, 1998), available at http://www.fas.org/irp/offdocs/pdd-62.htm [hereinafter PDD No. 62]; Presidential Decision Directive No. 63 (May 22, 1998), available at http://www.fas.org/irp/offdocs/pdd/pdd63.htm [hereinafter PDD No. 63].

69 Id. at 2.

$70 \quad$ Id. at 1.

71 EPA, EPA'S ROLE AND AUTHORITY IN COUNTER TERRORISM, at http://yosemite.epa.gov/ oswer/ceppoweb.nsf/content/ct-epro.htm (last modified Oct. 17, 2002) [hereinafter EPA's ROLE AND AUTHORITY].

72 PDD No. 39; PDD No. 62; PDD No. 63.

73 EPA FACTSHEET, supra note 67 , at 2.

74 Budget of the United States Government, Fiscal Year 200315 (2003) [hereinafter U.S. BUDGET 2003].

75 EPA's ROLE AND AUTHORITY, supra note 71.

76 2003-2008 EPA STRATEGIC PLAN, supra note 66, at 113-14. 
Capitol Hill, have further defined the nation's expectations of EPA's emergency response capabilities." 77

Is an expanded environmental role in homeland security within the EPA mission? Administrator Whitman wrote in her letter with the EPA Strategic Plan for Homeland Security that:

The terrorist attacks of September 11, 2001, transformed the Environmental Protection Agency's long-standing mission to protect the environment and safeguard human health in new and important ways. ...

With the United States under threat of attack from international terrorists and others who seek to do our country harm, EPA's traditional mission has expanded to include protecting our country against the environmental and health consequences of acts of terrorism. ${ }^{78}$

The role of EPA in Homeland Security is within EPA's stated mission, and the future of EPA's role is vital to the federal coordination of an effective biodefense. However, Administrator Whitman cautions "while the missions we are prepared to carry out are indispensable elements of any national effort to secure the homeland, there may, over time, be other federal departments or agencies better suited or able to carry out certain aspects of those missions."79 However, with another passing year, and the intervening organization of the Department of Homeland Security, these EPA functions in biodefense are still vital, and unique to EPA's capabilities.

The Environmental Protection Agency was criticized for both its increasing role in homeland security, as well as its handling of the World Trade Center cleanup effort. In response to this criticism for its changing role and the criticism that it

77 Office of Solid Waste and EMERgency Response, EPA, Fy 2004 Performance PRIORITIES FOR THE REGIONS $\S 3$ (2004), available at http:/www.epa.gov/ocfo/npmguidance/oswer/ fy04performancepriorities.pdf.

(3) Performance Priority: Homeland Security

Responding to small and large-scale disasters is one of EPA's traditional responsibilities. The Agency's crucial role in responding to the World Trade Center and Pentagon attacks, and the decontamination of anthrax at Capitol Hill, have further defined the nation's expectations of EPA's emergency response capabilities. The Agency will continue to play a unique role in responding to and preparing for future terrorist incidents, which could possibly be more devastating in scale and nature than those of September 11,2001, and could include bioterrorism or "dirty" bombs that affect the lives of millions of Americans and devastate the economy.

Performance Expectations for Regions: The FY 2004 budget provides additional resources for equipment, training, and establishment of a "Decontamination Team." We are facing FTE limitations, including a reduction of 55 FTE, from the level provided in the FY 2002 Counter-Terrorism Supplemental. OSWER Headquarters will work with the Regions and OCFO to address this shortfall. At the same time we face this challenge, we must continue to improve our readiness and response capabilities. The FY 2004 budget makes a commitment to establish a baseline for Agency preparedness in FY 2003, and formally report on that measure in FY 2004. Also, the Agency is striving to establish and maintain the capability to respond to simultaneous large-scale incidents, although, the resources in FY 2004 may not support the goal of responding to five such incidents as stated in the Agency's Homeland Security Strategic Plan.

Id.

78 EPA, STRATEgIC PLAN FOR HOMELAND SECURITY (2002), available at http://www.epa.gov/ epahome/downloads/epa_homeland_security_strategic_ plan.pdf [hereinafter SECURITY STRATEGIC PLAN].

79 Id. 
might have neglected its criminal enforcement duties as a result of the reallocation of resources, EPA issued a statement entitled "Correcting the record: EPA's Role in Homeland Security, Enforcement ..." in April 2003. EPA stated:

Since September 11, 2001 our government has experienced an enormous increase in the need to protect its citizens from acts of terrorism. . . . EPA responded immediately and continues to play a critical role in homeland protection. EPA's strategic plan for homeland security was held up as a model for other Agencies and Departments. . . EPA's focus since September 11 has been to support our nation's effort at combating domestic threats while at the same time ensuring that enforcement of environmental crimes continues. ${ }^{80}$

\section{B. Traditional National SECURity Exceptions}

Major federal environmental laws address issues of national security through national security exemptions. The Endangered Species Act ("ESA"), ${ }^{81}$ the Clean Water Act, ${ }^{82}$ the Clean Air Act, ${ }^{83}$ the Resource Conservation and Recovery Act ("RCRA"), ${ }^{84}$ and the Toxic Substances Control Act ${ }^{85}$ all provide for a national security exemption. The National Environmental Protection Act ("NEPA") has been interpreted to allow for environmental impact statements to be classified for national security reasons. ${ }^{86}$ These exemptions and interpretations can be important to homeland security priorities, although their primary effect is to conserve resources.

\section{Executive Actions that Do Not Require Amendments to Existing STATUTES}

The use of environmental laws in homeland security capitalizes on an existing, mature framework of federal environmental law. In the EPA's Strategic Plan, the agency committed to the goal of protecting critical infrastructure through "manage[ment of] its federal civil, and criminal enforcement programs to meet our homeland security, counter-terrorism, and anti-terrorism responsibilities under [the] Presidential Decisional Directives . . . and environmental, civil and criminal statutes." ${ }^{, 7}$ These Executive Branch actions operate within the delegated authority of Congress to the President through EPA.

\section{Biowatch}

Legislation was introduced after 9-11, to develop a system of biosensors for biological agents using "atmospheric remote detection technologies,"

80 OfFICE OF INSPECTOR GENERAL, EPA, EPA'S RESPONSE TO THE WORLD TRADE CENTER Collapse: Challenges, Successes, and AREAS for ImProvement (Rep. No. 2003-P-00012) (2003), available at http://www.epa.gov/oig/reports/2003/WTC_report_20030821.pdf.

81 Endangered Species Act of 1973, 16 U.S.C. $\$ 1536(\mathrm{j})(2000)$.

8233 U.S.C. $\S \S 1323,1316,1317(2000)$.

8342 U.S.C. $\$ 7418($ b) $(2000)$.

84 42 U.S.C. $\$ 6001$.

8515 U.S.C. $\$ 2621(2000)$.

86 Weinberger v. Catholic Action of Hawaii/Peace Education Project, 454 U.S. 139, 144

(1981).

2003-2008 EPA STRATEgiC PLAN, supra note 66, at 162.

88 Biological Agent-Environmental Detection Act of 2001, S. 1560, 107th Cong. $\S 3(2001)$. 
remained in committee during the congressional session. However, by January 2003, such a system had been developed by EPA, on executive authority-not congressional authority.

On January 22, 2003, the White House announced that there would be a deployment of environmental biosensors for surveillance of any presence of biological disease agents, ${ }^{89}$ in a program named "Biowatch." The more than 3,000 air quality monitors utilized in the monitoring of pollutants in the air comprise the network supporting Biowatch. ${ }^{90}$ Air quality monitors in undisclosed major cities have been fitted with air filters that are analyzed on a daily basis by one of 120 laboratories around the United States. ${ }^{91}$

On October 4, 2003, Biowatch received its first "hit." In Houston, the air monitors retrofitted with the Biowatch filters utilizing a daily collection process detected tularemia ${ }^{92}$ at two different air monitor sites on the east side of Houston. ${ }^{93}$ Again, on Sunday, October 5, 2003 and Monday, October 6, 2003 the detection of tularemia was confirmed for the monitors. ${ }^{94}$ The daily collection of paper-thin filters for crushing and analysis showed the presence of fragments of DNA of tularemia. ${ }^{95}$ The days that followed resulted in negative reads, and on October 9, 2003 the Houston Department of Health and Human Services, in co-authorship with Harris County Public Health and Environmental Services, issued a press release disclosing the discovery. ${ }^{96}$

The response to the discovery of the DNA fragments permits an examination of the federalism relationship between the state and federal government in a newly cooperative federalism area of surveillance of biological agents through a federal environmental statute. The Department of Energy, the CDC, and the EPA all collaborated in the development of Biowatch. EPA coordinated the location of the filters, and arranged for collection of the filters by contractors. ${ }^{97}$ It was estimated that the collection and processing of these filters would cost about one million dollars per year for each city. ${ }^{98}$ The monitors are overseen by the Texas Commission on Environment Quality ("TCEQ"), and upon discovery of the indication of tularemia, TCEQ notified the FBI, and the appropriate official was alerted. ${ }^{99}$ Concurrently, the confirmation process was underway, with samples being

89 Laura Meckler, Nationwide Monitoring System Planned for Detecting Bioterror Attack, AP NEWSWIRE, Jan. 22, 2003.

$90 \quad$ Id.

91 Judith Miller, U.S. Deploying Monitor System for Germ Peril, N.Y. TIMES, Jan. 22, 2003, at Al, Al0.

92 Tularemia is a potentially serious illness that occurs naturally in animals and because tularemia can spread to humans through airborne pathogens, the CDC has listed it as a bioterrorism agent. CDC, KEY FACTS ABOUT TULAREMIA, at http://www.bt.cdc.gov/agent/tularemia/facts.asp (last modified Oct. 7, 2003).

93 See News Release, Houston Department of Health and Human Services, Officials Following up on Bacteria Detection, at http:/www.ci.houston.tx.us/departme/health/bacteria\% 20detection.htm (Oct. 9, 2003) [hereinafter News Release].

94 Id

$95 \quad I d$.

96 Id.

97 See John Mintz, U.S. Provides a Peek at Air Sensor Program, Wash. Post, Nov. 15, 2003, at $\mathrm{A} 3$.

98 See id.

99 See News Release, supra note 93. 
sent to CDC to confirm that the DNA fragments were tularemia and not a false positive. ${ }^{100}$

This new, and major, biosurveillance role for EPA is being assumed through state programs which have been delegated program authority under the Clean Air Act. ${ }^{101}$ Because of this, the state TCEQ and not the local EPA office, was engaged in the process. A reassessment of the federal agency's role in homeland security began at EPA headquarters to question whether EPA should have a greater role. ${ }^{102}$ As announced on September 30, 2003 in the pre-publication copy of EPA's Strategic Plan, EPA was made the lead agency for the Biowatch system by the former Office of Homeland Security. ${ }^{103}$

The EPA Strategic Plan for Homeland Security, released in September 2002, made bold and sweeping commitments to its role in homeland security, yet its more recent Strategic Plan, released in September 2003, does little more than mention homeland security ${ }^{104}$-no components of EPA were moved to the newly created Department of Homeland Security. ${ }^{105}$ Any second EPA strategic plan for homeland security is very likely to show a significant withdrawal from the duties of homeland security, in part due to the lack of supporting congressional appropriations for the earlier, bolder commitments to homeland security by EPA. ${ }^{106}$

\section{FIFRA}

The Federal Insecticide, Fungicide, and Rodenticide Act ("FIFRA") ${ }^{107}$ provides that the EPA may "exempt any Federal or State agency from any provision of this subchapter if the Administrator determines that emergency conditions exist which require such exemption." 108 An act of bioterrorism meets the requirements for an "emergency condition." 109 The conditions for a crisis exemption exist when there is no time for review by EPA, and a temporary crisis exemption may be issued, effective for fifteen days. ${ }^{110}$ Crisis exemptions have been issued by EPA for the use of ethylene oxide application to decontaminate the congressional offices and the Department of Justice building; ${ }^{111}$ hydrogen peroxide and dimethylbenzyl ammonium chlorides were exempted for use on contaminated personal property; ${ }^{112}$

100 Id.

10142 U.S.C. $\$ \$ 7407,7410(2000)$.

102 2003-2008 EPA STRATEgIC PlAn, supra note 66, at 162.

103 Id. "[A]s a result of EPA's experience with air monitoring and indoor air quality issues, the then-Office of Homeland Security at the White House gave the Agency the lead for the Biowatch system. This system is being implemented in cities across the country to monitor for airborne release of certain biological contaminants." Id.

104 2003-2008 EPA STRATEgic PLAN, supra note 66, at 161-64.

105 U.S. DePartment of HoMEland SECURITY, DHS ORGanization: Who Will Be Part of THE NEW DEPARTMENT?, at http://www.dhs.gov/dhspublic/interapp/editorial/editorial_0133.xml (last visited July 22, 2004).

106 See U.S. BUDGET 2003, supra note 74

1077 U.S.C. $\$ \S 136-136$ y (2000).

108 Id. $\S 136 \mathrm{p}$.

109 See 40 C.F.R. $\S 166.3(2003)$.

110 Id. $\$ \$ 166.2(\mathrm{c}), 166.45$.

111 Pesticide Emergency Exemptions; Agency Decisions and State and Federal Agency

Crisis Declarations, 67 Fed. Reg. $6707 \S$ III.B (Feb. 13, 2002) (exemption issued Dec. 7, 2001, expiring in one year).

112 Id. (exemption issued Nov. 16, 2001, expiring in one year). 
chlorine dioxide gas for use in the Hart Senate Office Building; ${ }^{113}$ and methyl bromide was exempted for application in a vacant mobile home on the premises of the University of Florida. ${ }^{14}$ This emergency authority provides a framework to ensure that certain safety precautions are observed.

\section{Local Emergency Planning Committees}

The utilization of an existing national system of local emergency planning committees ("LEPCs"), mandated by the Emergency Planning and Community Right-to-Know Act, ${ }^{15}$ can provide at least a two-year savings in time ${ }^{116}$ for the implementation of any similar program for biodefense.

Another agency action which has the effective of bolstering the role of EPA in homeland defense was guidance issued in February 1998, for utilizing the LEPCs through expanding the local role in hazardous chemical emergencies to weapons of mass destruction emergencies. ${ }^{117}$ The guidance urged LEPCs to expand their current role of information collection and dissemination to the community to include biological agents and threats of bioterrorism, as well as threats of releases of hazardous substances. ${ }^{1 / 8}$ EPA issued guidance again in August 2001, for addressing terrorism activities in the local emergency plan, stating that "Local emergency planning committees should consider the possibility of terrorist events as they review existing pans and consider how to incorporate counter-terrorism ("CT") measures into their plans. CT planning and preparedness is often an extension of existing activities rather than a totally new effort." 119 Although the statute specifically directs the professional expertise of the membership of the LEPCs, ${ }^{120}$ the guidance urges that the committees include additional members who may have expertise in biological agents "(e.g., the coroner, morticians, chemistry and biology labs, university experts.)" 121 The logical extension of the LEPCs to include the disclosure to the public ${ }^{122}$ of the presence of biological agents in the community falls within a mission to provide residents with information about hazards that exist in their communities.

113 Id. (exemption issued Nov. 30, 2001, expiring in one year).

114 EPA, PEsticides: TOPICAl \& CHEMical FAct SHEets-Methyl BRomide, at http://www.epa.gov/pesticides/factsheets/chemicals/methylbromide_factsheet.htm (last updated Aug. $11,2003)$.

115 Emergency Planning and Community Right-To-Know Act of 1986 ("EPCRA"), 42 U.S.C. $\S$ $11001(2000)$.

116 Victoria V. Sutton, A Precarious "Hot Zone"-The President's Plan To Combat Bioterrorism, 164 MIL. L. REV. 135, 147 (2000); see also Vickie V. Sutton, Perceptions of Local Emergency Planning Committee Members Responsibility for Risk Communication for Risk Communication and a Proposed Model Risk Communication Program for Local Emergency Planning Committees Under SARA, Title III (1989) (unpublished Ph.D. dissertation, University of Texas at Dallas) (on file with author) (providing information on the formation of the local emergency planning committees ("LEPCs"); the designation of the LEPCs took one year, and an additional year to resolve a dispute concerning the delineation of planning districts).

117 EPA FACTSHEET, supra note 67.

118 Id

119 Chemical Emergency Preparedness and PREVEntion OfFice, EPA, LEPCS AND Deliberate Releases: Addressing Terrorist activities in the Local EMERgency Plan (Pub. No. EPA 550-F-01-005) (2001), available at http://yosemite.epa.gov/oswer/ceppoweb.nsf/content/staloc.htm [hereinafter LEPCS AND DELIBERATE RELEASES].

120 EPCRA, 42 U.S.C. $\S 11001$ (c).

121 LEPCS AND DELIBERATE RELEASES, supra note 119 , at 1.

12242 U.S.C. $\$ 11044$. 
The statute also includes the provision of public information of inventories of chemicals in the community, as well as emergency plans, ${ }^{123}$ which has been of concern since 9-11, yet objections from public interest groups in support of openness rejected any move to amend the statute. ${ }^{124}$

But contrast this proposed concern to know what biological agents are in the community with the movement to remove chemical "worst-case-scenario" information from the Internet. Due to increased concerns about chemical information available on the Internet, ${ }^{125}$ EPA revised the rule which makes data about the kinds and amounts of hazardous materials, plans and most importantly, an estimation of the impact of a release on the surrounding communities including human health impacts, commonly referred to as the "worst-case-scenarios." The statutory requirement to make this information available to the public was modified by action from EPA which removed the material from the Internet, and made it available in reading rooms with some restrictions on access. ${ }^{126}$ A proposed rule is expected to be final in 2004.

\section{Decontamination Is Led by EPA}

Prior to the anthrax attacks in the Fall of 2001, the EPA was designated as the lead agency in decontamination activity for any response to a biological terrorist event during the Clinton Administration. ${ }^{127}$ This role was utilized during the anthrax decontamination of the Hart Senate Office Building and other government buildings. ${ }^{128}$ The largest single budget item in homeland security for EPA in the following budget year was for decontamination activities to conduct research on technologies to decontaminate buildings which have been contaminated with a biological agent. ${ }^{129}$

Decontamination also includes the disposal of wastewater used to hose down workers after exiting a contaminated building. ${ }^{130}$ After decontamination of the American Media building in Boca Raton, Florida, EPA developed a protocol with the Agency for Toxic Substances and Disease Registry in October 2001 for treatment of the wastewater before disposal. ${ }^{131}$ The wastewater was used to water golf courses, Florida Atlantic University, and some of the city's southeastern neighborhoods. ${ }^{132}$

123 Id. (plans, material safety data sheets); id. $\$ 11022(\mathrm{e})$ (chemical inventories).

124 Kara Sissell, Right-to-Know Activists Consider Lawsuit Over RMP Data, ChEMICAL WEEK, April 28, 2004, at 13.

125 U.S. General ACcounting OfFice, Homeland Security: EPA's Management of Clean AIR ACT CHEMICAL FACILITY DATA, Rep. No. GAO-03-509R (Mar. 14, 2003).

12665 Fed. Reg. 48108 (Aug. 4, 2000).

127 PDD No. 39, supra note 72; PDD No. 62, supra note 72; PDD No. 63, supra note 72.

128 See Rafael Lorente, Congressman Mocks Plan to Buy AMI Building Closed by Anthrax, S. Fla. Sun-Sentinel, Feb. 11, 2003, at Al; EPA, Hart Senate OfFice Decontamination PROGRESSING, at http://www.epa.gov/epahome/headline_120301.htm (Dec. 3, 2001).

129 The President's 2003 budget requested $\$ 124$ million in new funding for a total EPA investment of $\$ 133.4$ million for homeland security. Of the total EPA budget, $\$ 75$ million was dedicated to decontamination activities. U.S. BUDGET 2003, supra note 74.

130 See Kathy Bushouse, AMI Test Water Was Cleaned, Dumped: Officials Say Waste Had Been Made Safe, S. Fla. Sun-SENTINEL, Sept. 20, 2002, at BI.

131 Id.

$132 I d$. 


\section{AmEndments to Existing StatuTES}

The Public Health Security and Bioterrorism Preparedness and Response Act of $2002,{ }^{133}$ in Title V, amended the Safe Drinking Water Act to require systems subject to regulation under the act to develop safety plans to counter the threat of terrorism. ${ }^{134}$ Upon receipt of the plan by the EPA Administrator, it is protected from disclosure to the public, not through the national security exemption ${ }^{135}$ of the Freedom of Information Act ("FOIA"), ${ }^{136}$ but through a specific exemption from the requirements of FOIA. ${ }^{137}$ It does not protect the plans from local and state open records or "sunshine" acts. ${ }^{138}$ All fifty states have some form of a FOIA-type statute, ${ }^{139}$ which rely upon judicial determinations or provide for access to state information through their state constitution. ${ }^{140}$ EPA has urged states to amend their statutes with regard to disclosure of security plans for water systems. ${ }^{141}$

\section{E. JUDICIAL INTERPRETATION OF EXISTING FEDERAL ENVIRONMENTAL LAW TO INCLUDE BIOLOGICAL THREATS}

\section{Cleanup Actions in Response to Bioterrorism: RCRA and CERCLA}

During the anthrax attacks, a circuit court was asked to issue an injunction to examine the U.S. Postal Service's cleanup plan for the Morgan Processing Center in New York. ${ }^{142}$ The plaintiffs asked for the injunction using two federal environmental statutes, RCRA and the Comprehensive Environmental Response, Compensation, and Liability Act ("CERCLA"), ${ }^{143}$ which provides for citizen action to require a plan for cleanup that meets the standards of the National Contingency Plan. ${ }^{44}$ In the first case, the U.S. Postal Service took the position that anthrax did not meet the definition of "solid waste" as required to trigger a RCRA cleanup. ${ }^{145}$ Solid waste is defined as, "any garbage, refuse sludge from a waste treatment plant, water supply treatment plant, or air pollution control facility and other discarded material, including solid, liquid, semisolid, or contained gaseous material resulting from industrial, commercial, mining, and agricultural operations, and from community activities." 146 CERCLA defines "pollutant or contaminant" as "any element, substance, compound, or mixture, including disease-causing agents, which

133 Pub. L. No. 107-188, 116 Stat. 633 (2002).

13442 U.S.C. $\$ 300 \mathrm{i}-2(2000)$.

1355 U.S.C. $\S 552(\mathrm{~b})(1)(2000)$.

136 Id. $\S 552$.

137 Public Health Security and Bioterrorism Preparedness and Response Act of 2002, Pub. L. No. 107-188, 116 Stat. 633, sec. 401 (2002).

138 association of Metropolitan Water agencies, State fola laws: a Guide To Protecting SENSITIVe WATER SECURITY INFORMATION (2002), available at http://www.amwa.net/ security.

139 Id.

140 See, e.g., MONT. CONST. art. II, §9.

141 Bush Signs Anti-Terrorism Bill Into Law Requiring Drinking Water Threat Assessments, 1332 BNA ENV'T. REP. (June 14, 2002).

142 Smith v. Potter, 187 F. Supp. 2 d 93 (S.D.N.Y. 2001).

143 Comprehensive Environmental Response, Compensation, and Liability Act of 1980, Pub. L. No. 96-510, 94 Stat. 2767 (1980) (codified in scattered sections of 42 U.S.C. and 26 U.S.C.).

14442 U.S.C. $\$ 9659$ (2000).

145 Smith, 187 F. Supp. 2 d at 98.

14642 U.S.C. $\$ 6903(27)(2000)$. 
after release into the environment and upon exposure, ingestion, inhalation, or assimilation into any organism, either directly from the environment or indirectly by ingestion through food chains will or may reasonably be anticipated to cause death [or] disease." ${ }^{147}$ In order to trigger a RCRA cleanup, however, the definition of solid waste had to be met, and the U.S. Postal Service argued that anthrax was not a "solid waste" triggering the citizen suit. ${ }^{148}$ However, the action was filed again several months later, and the Postal Service changed their position-anthrax was a solid waste. ${ }^{149}$ The Postal Service made this concession with a caveat:

[T]he Government does not maintain that anthrax, per se, is a 'solid waste' under RCRA, or that RCRA applies in every context in which anthrax may be present. Whether RCRA applies in every context in any case involving anthrax requires a fact-specific analysis, which in turn considers whether the anthrax at issue has been discarded. ${ }^{150}$

\section{Eradication of Smallpox, NEPA, and the ESA}

Although no litigation has been initiated to prevent the eradication of the remaining smallpox virus, as planned by the World Health Organization, federal environmental laws most applicable to this consideration are NEPA and the ESA. ${ }^{151}$

Examining NEPA, the statutory mandate requires that an environmental impact statement be made for "any major federal action significantly affecting the quality of the human environment." 152 The CDC, which holds one of the U.S. samples of smallpox, might be required to examine the applicability of this statute. Although the effect on the human environment may be positive, courts have interpreted "effects" to include both positive and negative effects on the environment, requiring only a human alteration of the environment. ${ }^{153}$

The ESA protects fish or wildlife and excludes any insect that might be considered a pest, presenting an "overwhelming and overriding risk to man." virus is not included in the protections of the ESA, and it is inconceivable that Congress would intend to eradicate an insect that might be a pest while preserving a virus that was a serious public health threat.

\section{EMERGING DISEASES AND THE ENVIRONMENT}

The problem of emerging infectious diseases in the world has become evident, and the role of the changing environment as either a natural cycle or as a humancreated phenomenon has been a contributing factor to this change in environment.

147 Id. $\S 9601(33)$.

148 Smith, 187 F. Supp. 2 d at 98.

149 Smith v. Potter, 208 F. Supp. 2d 415, 418 (2002).

150 Id. at 418 n.2.

151 See David A. Koplow, Smalípox: The Fight to Eradicate a Global Scourge 124-36 (2003).

15242 U.S.C. $\$ 4332(2000)$.

153 Douglas County v. Babbitt, 48 F.3d 1495, 1505 (9th Cir. 1995). "NEPA procedures do not apply to federal actions that do nothing to alter the natural physical environment," and the court explains, "when a federal agency takes an action that prevents human interference with the environment, it need not prepare an EIS." 1 . at 1506.

15416 U.S.C. $\S 1532(6)(2000)$. 
Cycles of hantavirus, ${ }^{155}$ occurring during especially wet spring seasons, evident from the historical sand paintings and the oral histories of the Navajos predating U.S. governmental records, are an example of increasing rains as a trigger for a disease cycle. ${ }^{156}$ However, evidence of meningitis epidemics in South Africa, occurring with dry seasons, low humidity, and dusty conditions, and disappearing with the onset of the rains, indicates that it is not only wetter climate patterns that can trigger epidemics. ${ }^{157}$

Infectious pathogens are being affected by climate and weather patterns. ${ }^{158}$ Natural disasters also occur as a result of shifts in climate and weather patterns, which often lead to disruption of communities and the development of temporary shelters, which inevitably provide a natural setting for the transmission of diseases in a densely populated community of displaced victims of these natural disasters. ${ }^{159}$

\section{FUTURE ROLE OF THE U.S. EPA}

\section{A. Mosquitoes and Wetlands Regulation}

On August 15, 2003, President George W. Bush signed into law the Mosquito Abatement for Safety and Health Act, ${ }^{160}$ authorizing grants through CDC for mosquito control and to prevent mosquito-borne diseases and for other purposes. ${ }^{161}$ The act requires EPA to consider the use of pesticides and what impact that use will have on public health. ${ }^{162}$

Could it be possible that we have come full circle in the management of wetlands? Wetlands have not always been seen as useful. One of the first appropriations of the Continental Congress was for $\$ 300$ to purchase quinine for protection of the troops from malaria. ${ }^{163}$ An important U.S. policy for land development included draining wetlands in order to reduce mosquito populations and the malaria they brought. ${ }^{164}$ Some believe that protecting wetlands is inconsistent with public health, and argue that we cannot protect both wetlands and public health. ${ }^{165}$

155 Hantavirus is a deadly disease transmitted by infected rodents through urine, droppings, or saliva which humans can contract when they breathe in aerosolized virus. NATIONAL CENTERS FOR INFECTIOUS DISEASES, CDC, ALL ABOUT HANTAVIRUSES, at http://www.cdc.gov/ncidod/diseases/ hanta/hps (last reviewed July 8, 2004).

156 See Lori ARviso Alvord \& Elizabeth Cohen VAN PElt, The SCALPEl and the Silver BEAR 120-27 (1999).

157 See Anna M. Molesworth et al., Environmental Risk and Meningitis Epidemics in Africa, 9 EMERGING INFECTIOUS DISEASES 1287 (2003).

158 Paul R. Epstein, Enhanced: Climate and Health, 285 SCIENCE 347 (1999).

159 M.F. Lechat, The Epidemiology of Health Effects of Disasters, 12 EPIDEMIOLOGICAL REVIEWS 192(1990) (2003).

160 Mosquito Abatement for Safety and Health Act of 2003, Pub.L. No. 108-75, 117 Stat. 898

$161 \mathrm{Id}$.

162 Id

163 Robert S. Desowitz, The Malaria Capers: More Tales of Parasites and People, RESEARCH AND REALITY (1991).

164 Thomas E. Dahl, U.S. Department of InTERIor, Fish \& Wildlife Service, Wetlands LOSSES IN THE UNITED STATES, 1780 TO 1980s (1990).

165 Saving the Ecosystem ... for the Mosquitoes, 8 DOCTORS FOR DISASTER PREPAREDNESS NEWSL. (1991), at http://www.oism.org/ddp/ddpnews/ddpnov91.html. 
Two centuries later, the Clean Water Act provided for the protection of wetlands, based on the Commerce Clause authority over navigable waters, and charging EPA with environmental oversight. ${ }^{166}$ Should West Nile fever, or other mosquito-borne disease, become such a hazard that it requires drastic destruction of mosquitoes and other natural hosts and vectors, EPA might be balancing the risk of broad applications of pesticides which will be sure to harm other parts of the ecosystem, verses draining wetlands which could reduce the population of mosquitoes. Could EPA find that, on balance, the loss of wetlands is less costly to public health than the eradication of mosquitoes? Should EPA take on the role of balancing the interests of environmental protection and public health?

\section{B. EPA AND INTERNATIONAL EXPERIENCE}

EPA has been at the center of international negotiations for environmental protection, including such important agreements as the Montreal Protocol, an international approach to reduce and reverse ozone depletion, ${ }^{167}$ and the development of the Kyoto Protocol for global climate change responses. ${ }^{168}$ The need to begin to develop an international public health agreement has been evident with the recent SARS outbreak, which originated in China. An international protocol for addressing the important needs of communicating information about public health to the world community and the development of protocols for preventing the kind of spread of SARS that resulted from the delay in addressing the outbreak through the World Health Organization ("WHO") is a next step response to this event, and should involve the participation of EPA, because of their expertise and international experience in areas involving the impact on public health in the context of the environment. EPA should play a major role in the development of public health protocols with WHO.

\section{CONCLUSION}

Environmental protection and public health have been common goals for a healthy population. The new threat of bioterrorism demands that we utilize existing federal environmental law systems through the role of the U.S. Environmental Protection Agency; amendments to existing federal environmental laws; application of existing federal environmental laws to new issues in bioterrorism; and judicial interpretations of these laws in the context of bioterrorism-related controversies. The evolution of public health law is following a pattern of development of cooperative federalism, seen in the last half century with the development of federal environmental law. In conclusion, the post 9-11 world will demand that public health be addressed through the environmental law system, and become more like the federal environmental law system.

The relationship of environmental law and public health law has historically been interdependent and promises to continue to be so in the context of bioterrorism.

16633 U.S.C. $\S 1251(2000)$.

167 United Nations Environment Programme, The Montreal Protocol on SUBSTANCES THAT DEPLETE THE OZONE LAYER (2002), available at http://www.unep.org/ozone/ Publications/6iv_publications\%20others.asp.

168 Kyoto Protocol to the United Nations Framework Convention on Climate Change, Dec. 11, 1997, 37 I.L.M. 22 (entered into force Mar. 21, 1994), available at http://unfecc.int/resource/ convkp.html. 
The use of the U.S. Environmental Protection Agency in cooperation with the Department of Homeland Security will enable the utilization of existing human resources in enforcement and in the shaping of environmental programs which also include elements of biodefense, through executive branch responses within the mission of EPA. Where amendments to existing federal environmental laws can enhance the ability to provide for homeland security, such as the Safe Drinking Water Act Amendments of 2002, they also provide for not only the utilization of existing resources for homeland security in an economical sense, but it also speed the development of institutional mechanisms to use for homeland security needs.

Public health law, an area of traditional state sovereignty, is shifting to more federal or national authority, as suggested in recent legislation and the announcements of President George W. Bush in his organizational plan for a Department of Homeland Security. ${ }^{169}$ In fact, the shift in federalism is analogous to that of environmental law, an area of traditional state sovereignty in property, specifically using water as an example.

Former Administrator Christine Todd Whitman, signed a strong plan for homeland security in 2002 , and this is no time - in a time of plague ${ }^{170}$ - to reverse that strong course that has been set in motion.

169 See infra Part II.B.

170 The origin of this phrase is not certain, but this author first identifies it from a letter (circa 1620) from Sir Drummond, a Scottish poet and author to Sir Robert Ker in response to a duel, won by Sir Ker: "Ye are too good for these times, in which, as in a time of plague, men must once be sick, and that deadly, ere they can be assured of any safety." A portion of this letter is available at http://www.electricscotland.com/history/other/drummond_william.htm (last visited July 22, 2004). 